$$
\text { CONF - 840405- - } 14
$$

UCRL- 89988

\title{
PREPRINT
}

\section{Selection of Candidate Canister Materials for High-Level Nuclear Haste Containment \\ in a Tuff Repository}

\section{R. D. McCright}

H. Weiss

M. C. Juhas

R. W. Logan

\author{
National Association of Corrosion Engineers ' \\ Annual Meeting \\ New Orleans, Louisiana \\ Apri1 1, 1984
}

November 1983

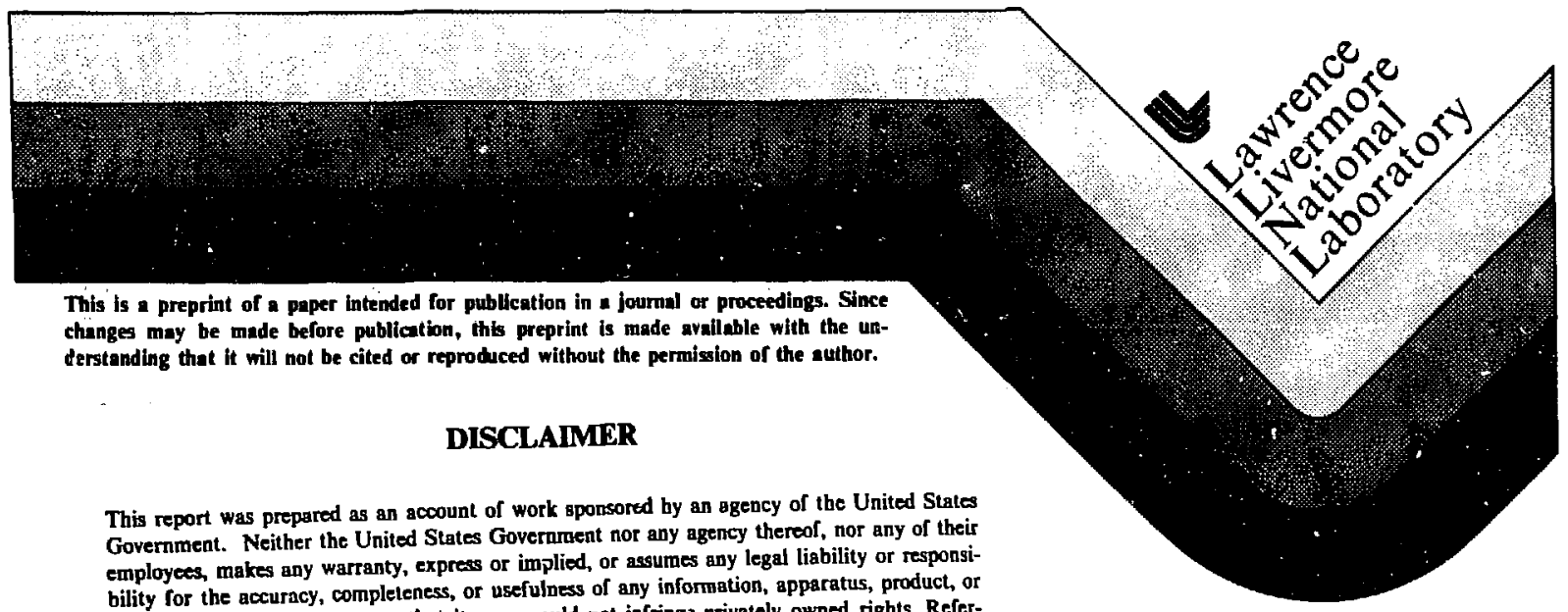
 process disclosed, or represents that its use would not infring: privately owned rights. Reference berein to any specific commercial product, process, or service by trade name, trademark, manufacturer, or otherwise does not necessarily constitute or imply its endorsement, recommanufacturer, or otherwise doe United States Government or any agency theresf. The views and opinions of authors expressed herein do not necessarily state or reflect those of the United States Government or any agency thereof. 


\title{
SELECTION OF CANDIDATE CANISTER MATERIALS FOR HIGH-LEVEL. NUCLEAR
} WASTE CONTAINMENT IN A TUFF REPOSITORY

\author{
R. D. McCright, H. Weiss, M. C. Juhas \\ Lawrence Livermore National Laboratory \\ Livermore, CA 94550
}

$\begin{array}{cc}\text { R. W. Logan } & \text { UCRL- }-89988 \\ \text { University of Michigan } & \text { DE85 } 003567 \\ \text { Anr Arbor, MI } 48109 & \end{array}$

Prepared for Presentation at the

National Association of Corrosion Engineers Annual Meeting New Orleans, April 1, 1984

\section{ABSTRACT}

A repository located at Yucca Mountain at the Nevada Test Site is a potential site for permanent geological disposal of high level nuclear waste. The repository can be located in a horizon in welded tuff, a volcanic rock, which is above the static water level at this site. The environmental conditions in this unsaturated zone are expected to be air and water vapor dominated for much of the containment period. Type 304L stainless steel is the reference material for fabricating canisters to contain the solid high-level wastes. Alternative stainless alloys are considered because of possible susceptibility of 304L to localized and stress forms of corrosion. For the reprocessed glass wastes, the canisters serve as the reripient for pouring the glass with the result that a sensitized microstructure may develop because of the times at elevated temperatures. Corrosion testing of the reference and alternative materials has begun in tuff-conditioned water and steam environments.

*Work performed under the auspices of the U.S. Department of Energy by the Lawrence Livermore National Laboratory under contract number W-7405-ENG-48. 
Introduction

- awrence Livermore National Laboratory (LLNL) is responsible for high-level nuclear waste package development as part of the Nevada Nuclear Waste Storage Investigations (NNWSI) Project. This project is part of the Department of Energy's Civilian Radioactive Waste Management (CRWM) Program. The waste package effort at LLNL is developing multibarriered packages for safe, permanent disposal in the proposed Yucca Mountain tuff repository.

The purpose of this paper is to provide a discussion of corrosion-related concerns in selecting metal barrier materials to contain high-level nuclear waste for long-term geological disposal in a tuff repository. The plan of this paper is to describe in some detail the geochemical environment, particularly as it is expected to influence the corrosion and oxidation behavior of candidate metals and alloys. roposed reference and alternative construction materials for containers are discussed with regard to their expected performance; a test plan is outlined for determining whether these predictions hold for long term containment. Finaliy, available test results are presented and discussed.

The approach in nuclear waste package designs is to develop a system of redundant engineered barriers whose function is to contain radionuclides for several centuries. As a minimum, the package is composed of a waste form and a canister. Some waste package designs call for another outer metal barrier to act as an overpack. Some designs consider a packing material (backfill) placed around the outer metal barrier. Its primary function is to sorb any radionuclides which have migrated through a corroded or otherwise breached metallic barrier. As the environmental conditions in a tuff repository are expected to be rather "benign", the reference design consists of a single metal barrier, called a canister, surrounding the waste form. This paper is focused on selecting materials for that canister. Further discussion or. conceptual designs for different waste forms and configurations in a tuff repository is found in Reference 1 . 
Tuff deposits at the Nevada Test Site (NTS) are under investigation as a potential nuclear waste repository site. A particular lucation is the Yucca Mountain area in the southwestern corner of the NTS. Tuff is an igneous rock of volcanic origin and is composed of volcanic rock fragments (shards) and ash. During an eruption, the shards and ash are propelled by gases and are deposited downslope from the crater. In the Basin-and-Range area of the United States (which includes the NTS), the age of these deposits is estimated at between 8 and $2.7 \mathrm{million}$ years old. Deposits of tuff exceed $3000 \mathrm{~m}$ in thickness and lateral ranges of tens of kilometers occur in certain locations. Because of the underground nuclear testing at the NTS, these deposits have been extensively characterized.

The structure of the tuff deposits depends on the the cooling rate and degree of compaction after the volcanic eruption. The rock shards weld together and the compacted material may remain glassy or may devitrify. A lavered structure develops - a densely welded core surrounded above and below by zones of material decreasing in density and strength. In the post-depositional period, alteration of the tuff layers occurs. Crystallization transforms the glassy material to feldspar plus quartz or cristobalite. Zeolitization produces hydrous silicates by reaction of the glassy material with groundwater. A typical stratigraphy of the tuff at the NTS is shown in Figure 1. A more detailed description of these tuff layers is found in Reference 2 .

The static water level in the Yucca Mountain lies about $530 \mathrm{~m}$ (1660 ft) below the surface. A nuclear waste repository could be located in a horizon above this depth in the welded devitrified zone. This horizon would be in the Topopan Spring member. Among the advantages of locating a repository in this so-called unsaturated zone are the expected reduction in the severity of the corrosive environment due to minimum water and the elimination of a hydrostatic stress component on the waste package. Further advantages to locating the repository in the welded zone are the higher thermal conductivity and higher compressive strength of the tuff in this zone. The chemical composition of the welded tuff in this zone is given in Table 1 (2). 
The ambient temperature in the repository horizon is expected to be $29^{\circ} \mathrm{C}$. The rock unit is a densely welded, devitrified tuff with a small percentage of lithophysal cavities. The rock is estimated to contain about five persent water by volume (porosity of $12 \%$ ). The repository horizon is somewhat fractured with an average fracture density of 0.8 to 3.9 fractures per meter (3). While water samples have not yet been obtained from the location of the repository, near-by well J-13 produces water which has flowed through the Topopah Spring Member where it lies at a lower elevation and is in the saturated zone. ihe water from J-13 well is taken as a reference water in the repository horizon. The chemical composition of J-13 water is given in Table 2 (2). The vater is oxic and contains 5.7 ppm dissolved oxygen. The low concentrations of halide ions sugges:; that the water should not be aggressive toward stainless steels; however the oxidizing nature of the water makes it corrosive toward carbon steels. The low average rainfall at the NTS creates a low downward infiltration rate for water. The downward flux of water at the repository horizon is estimated at $8 \mathrm{~mm} /$ year.

\section{Waste Forms}

Three forms of high level nuclear waste may go into a tuff repository. These are (1) spent fuel (SF) from commercial light water nuclear reactors; (2) commercial high level waste (CHLW), which is a borosilicate glass containing the high-level fission products from reprocessing of spent fuel pins; and (3) defense high-level waste (DHLW), which is also a borosilicate glass and is manufactured from the high-level liquid radioactive wastes accumulated from different defense installations.

The spent fuel waste form consists of Zircaloy-clad fuel pins from pressurized water reactors (PWR) and boiling water reactors (BWR). The spent fuel pins vary in dimension for the different reactor types and models, but in general contain $\mathrm{UO}_{2}$ pellets, fission products, and actinides enclosed in the cladding. Fuel pellets of $\mathrm{UO}_{2}$ undergo physical and chemical changes during irradiation. The products are generally segregations of oxide compounds which have low solubility in $\mathrm{UO}_{2}$ or elements which are metallic under the redox conditions in the fuel. During irradiation, a small number of fuel pins may develop cladding defects. Fuel pins are combined in assembly units for 
loading into the reactors. For geological disposal the entire assembly may be packed into canisters or the assemblies may be disassembled and the fuel pins repacked into canisters. The heat output of spent fuel depends on the length of time since the fuel was ramoved from the reactor and the degree of burn-up while in the reactor. During the first ten years after removal from the reactor, the heat output from spent fuel decreases sharply. This is due to the decay of short-lived fission product isotopes. After ten years, the decay of longer-lived isotopes such as $\mathrm{Cs}-137$ and $\mathrm{Sr}-90$ control heat production, and the heat output decay is slower.

Commercial high level waste forms will result from reprocessing of spent commercial reactor fuel in order to separate potentially usefui components such as $U$ and $P_{u}$ from the fission products and higher actinides. The proposed method of preparing spent fuel for reprocessing involves chopping the Zircaloy-clad fuel into short lengths and dissolving the fuel in acid (chop-leach process). The $P U$ and $U$ will be separated from the other components by a solvent extraction process (Purex process). At present, there is no operating reprocessing plant for commercial spent fuel in the United States. Borosilicate glass formulations have been developed in support of the proposed reprocessing facility at Barnwell, SC. Glass compositions are chosen for solidification of $\mathrm{CHLW}$ so that process temperatures $c$ an be 10 enough to limit losses of radionuclides due to volatilization while maintaining a high chemical durability in the final giass. Boron is used in most waste glass formulations because it lowers the glass viscosity, and thus processing temperature, and increases the solubility of waste oxides in the silicate glasses. The favorable aspects are achieved at the cost of a reduction in chemical durability as the boron content is increased. High silica glasses are generally more resistant to chemical attack and dissolution than low-silica glasses. However, high silica content increases the viscosity and, hence, processing temperatures. Work is in progress for optimizing tne formulation for CHLW. (4)

Defense high-level waste results from processing sludge and supernatant high-level liquid wastes. These are currently stored at three different sites in the United States, but the process which has been developed at the Savannah River Laboratory is the most developed to date. The formulation has been 
described by Baxter (5). A solvent extraction process is used but the resulting glass contains more iron, aluminum, and zeolite than CHLi glasses. For geological disposal, the molten DHLW glass is poured into a stainless steel canister at a pouring temperature of $1050-1100^{\circ} \mathrm{C}$. About 17 hours are required to fill the canister and several additional hours are required to cool the glass casting and canister to ambient temperature. Measured peak surface temperatures of $550^{\circ} \mathrm{C}$ are developed on the outside of the canister during the slow pouring operation. The times at these elevated temperatures may create a sensitized microstructure which may then be susceptible to localized and stress-assisted forms of corrosion in aqueous environments. This point will be developed more fully in a later section. Partly to avoid the sensitization concerns, Type $304 \mathrm{~L}$ stainless steel canisters are proposed for use in the Savannah River process. The excellent oxidation resistance of this material during the pouring and cooling operations is an important factor in this selection. During the pouring operation, the outside surface of the canister is radioactively contaminated. The surface is cleaned off by an abrasive process after the pour; a canister material with minimal scale formation is desirable to minimize this burden. This burden is added to the filled canister. The canister is then sealed with a $304 \mathrm{~L} \mathrm{plug}$ which is upset resistance welded to the canister. While further process development is likely, the Savannah River process can be viewed as prototypic for both DHLW and CHLW glasses.

\section{Modification to Repository Environment}

Emplacenent of waste packages in the tuff repository will result in physical and chemical changes in the rock and groundwater system. These changes are due primarily to the therinal and radiation fields generated by the waste forms within the packages. Decay of radionuclides transfers kinetic energy to the decay products, and collisions of these decay products with the surrounding materials converts this energy into an increase in temperature. The dissipation of the decay product kinetic energy is referred to as the power output of the waste form. For any high-level waste form, the power output is nighest when the waste is youngest; it decreases as the radionuclides are transformed into stable, non-radioactive nuclei. Many of the fission products present in spent fuel and reprocessed waste have short 
half-lives. Thus, the power output of the waste will decrease rather rapidly during the first few decades of storage.

As each type of waste package will have a different inventory of radionuclides, the initial power output and rate of decrease of the power output is difierent. Representative expected thermal histories of emplaced waste packages are shown in Figure 2. These temperature-time profiles were calculated by a heat.transfer code and assume the package dimensions given in Table 3. The highest canister surface temperature will develop on the CHLW package because of the small diameter of the canister. While the spent fuel packages have higher power loads, the larger diameter and larger canister surface areas will reduce the surface temperature. The lowest temperatures will occur on the defense waste packages because of the lower power load and larger canister diameter. All of these calculations were based on a $50 \mathrm{~kW}$ per acre areal thermal loading at the time of emplacement. Spent fuel contains long-lived radioactive species, such as plutonium, which are present only at low levels in CHLW. Therefore, the power output from spent fuel packages will drop more slowly, and after about 50 years the canister surface temperatures will be higher on the spent fuel packages.

Immediately following waste package emplacemert, the rock and its associated pore water will undergo a temperature increase. As the temperature rises, water will be driven away from the waste package. When the rock temperature rises ahove about $95^{\circ} \mathrm{C}$ (estimated boiling point at horizon elevation in Yucca Mountain), all the liquid water in the rock will vaporize. The atmosphere in the pore spaces and around the waste packages will then consist of a mixture of air and steam. As the temperatures in the rock cools below $95^{\circ} \mathrm{C}$, water will slowly migrate back into the rock pores. This resaturation of the rock around CHLW packages will require times on the order of hundreds of years; in the case of spent fuel packages, resaturation may take thousands of years.

The mineral assemblage in the rock will be affected only in a small way by the imposed thermal field. The main minerals, quartz and alkali feldspar, will remain stable during the thermal period. Cristobalite, which in some samples is sometimes present at levels as high as $40 \%$ in Topopah Spring tuff, 
undergoes a phase inversion at around $250^{\circ} \mathrm{C}$ with a volume increase. Some or all of the volume expansion of the cristobalite may be taken up by a decrease in the rock $p$ osity. As water begins to return to the repository herizon, it will pass through a temperature gradient. The incoming water may interact with the rock. As the water migrates through increasing rock temperatures while descending through the repository horizon, the water may dissolve silica in increasing amounts. After passing through the maximum temperature zone, the water will cool and precipitate silica. This may lead to the partial or complete sealing of some fractures and/or rock matrix permeability below the waste packages. If sealing were complete, there could be isolated accumulation of small amounts of standing water. Because of the low amount of initial pore water and the low average amount of pluvial water, it is reasoned that only a small proportion of the packages could encounter these conditions. Some experimental work has been performed by contacting crushed Topopah Spring tuff with J-13 water at 150 and $90^{\circ} \mathrm{C}$. These data are given in Table 4. Experimental details are available (6). When these data are compared to the initial J-13 composition (Table 2), the main differences are the increase in silica levels; the potassium has apparently replaced calcium and magnesium. From the viewpoint of corrosion of stainless steels, the concentration of halide ions is little changed, and the nigher pH may be beneficial.

When the waste packages are first emplaced, the radiation produced within the packages will be at the maximum. Short-range radiation (such as alpha and beta particles) will be completely contained within the packages. The only radiation outside the waste packages are neutrons and gamma rays. The neutrons will interact mainly within the rock, but the experied neutron flux is too low to cause any substantive lattice displacement in any of the mineral phases. The interaction of gamma radiation with solids will not cause any significant permanent structural damage in these materials. The interaction of gamma radiation with liquids and vapors, however, is significant because of chemical bond breaking. Because of the higher mobility of species in the fluid phase, the molecular fragments can become separated and combine with fragments produced from other radiolysis reactions. The probability of new chenical species forming depends on the lifetime of the radiolys is products and on the density of the products in the fluid. Thus, chemical changes due to radialysis are dependent on the dose rate. 
The gamma radiation field is due mainly to gamma rays associated with decay of fission products. Most of the fission products have relatively short half-lives and are largely decayed to stable daughter products within the first hundred years. For example, the gamma flux 100 years after emplacement of CHLW is only $10 \%$ of the original flux at emplacement. Radiolysis products formed in the steam/air mixture surrounding the packages will possibly enhance the oxidation rate of the canister surface. Because stainless steels are proposed as canister materials, this modest increase in oxidation rate will likely only stabilize the usual protective, passive film on these alloys. By the time aerated liquid water can contact the canister surface, the reduced gamma flux should lower concentrations of radiolysis-produced species. Radiolysis products of concern in air-saturated water include the decomposition of water to elemental $\mathrm{O}_{2}$ and $\mathrm{H}_{2}$ as we?l as formation $\mathrm{H}_{2} \mathrm{O}_{2}, \mathrm{HO}_{2}$, and oxides of nitrogen including anhydrous nitric acid. These species are usually not corrosive to stainless steels, except when the stainless steel is in the sensitized condition.

\section{Reference and Alternative Materials for Canisters}

Type 304L stainless steel serves as the reference construction material for $r$ anisters. This material is expected to have excellent general corrosion resistance in air and steam at temperatures in the range $95-300^{\circ} \mathrm{C}$ and in non-saline, near-neutral pH, oxic waters below $95^{\circ} \mathrm{C}$. Water from the J-13 well has these characteristics. A conservative estimate of the wastage of $304 \mathrm{~L}$ during the containment period (up to 1000 years) shows a loss of $0.1 \mathrm{~cm}$ fron a $1-\mathrm{cm}$ thick canister wall. This estimate was based on "high values" of uniform corrosion and oxidation rates in water, steam, and air (7) and assumed linear oxide growth kinetics.

The limiting use conditions of $304 \mathrm{~L}$ stainless steel are rarely general corrosion wastage, but rather occur by much more ripid penetration via localized or stress-assisted forms of corrosion. The experimental test plan is: cherefore, largely aimed at resolving the likelihood of these forms of corrosion occurring during the containment period. For purposes of organization, the localized/stress forms of corrosion can be placed into two

groups: (1) corrosion forms favored by a sensitized microstructure. Such a 
microstructure can develop during the fabrication and welding of the canister, the glass pouring operation (DHLW and CHLW waste packages) or at relatively low temperatures during storage in the repository at canister surface temperatures in excess of, say, $150^{\circ} \mathrm{C}$ ( $\mathrm{CHLW}$ and SF waste packages). The sensitized microstructura may lead to intergranular corrosion (IG) or intergranular stress corrosion cracking (IGSCC) because of the expected oxidizing nature of the aqueous environment should it come in contact with the canister surface. (2) Corrosion forms favored by concentration of the different chemical species in J-13 water. Fractures in the host rock above the repository could admit episodic surges of water; plugging of fractures below the repository could retain this water for some period of time. Contact of the water with the hot canister surface would concentrate electrolytic species by evaporation of water. The chloride-ion concentration is of paramount concern with regard to resistance of stainless steals to localized and stress-assisted forms of corrosion. The other ions present in J-13 water may tavor or retard these kinds of corrosion attack. Radiolys is of the aqueous environment can cause chemical changes in the water and the dissolved species which, in turn, influence the form and rate of corrosion. Pitting attack, crevice attack, and transgranular stress corrosion cracking (TGSCC) are forms of corrosion that can develop on 304L in concentrated electrolytes -- particularly in high chloride solutions.

While the corrosion literature abounds in information on passive film breakdown and localized and stress corrosion initiation, it is difficult to apply this information without qualification to new sicuations in an attempt to specify critical levels of ioric concentrations, temperature, and stress below which the stainless steel is "safe" from these kinds of attack. The review by Nuttall and Urbaric (8) on materials for nuclear waste containment summarized available data from many sources. They indicated chloride ion concentrations on the order of several hundred ppm are needed before crevice corrosion develops on 304 stainless steel in the $50-100^{\circ} \mathrm{C}$ temperature range. When this value is compared to the $7 \mathrm{ppm} \mathrm{Cl}$-level in $\mathrm{J}-13$ (Tables 2 and 4), one would conclude that $\mathrm{J}-13$ is "safe" to 304 (and by extension to 304L) stainless steel. However, a boiling concentration mechanism on the surface could change that conclusion. 
Alternative materials were thus chosen for experimental testing should $304 \mathrm{~L}$ stainless steel be subject to the kinds of corrosion discussed abo/e. The alternative materials were chosen on the basis of their known improvenents in resistance to specific forms of corrosion. If sensitization effects and resulting intergranular corrosion/intergranular stress corrosion cracking develop, a stabilized grade of stainless steel such as Type 321 or Type 347 may show improved resistance. Premium grades of 304 with even lower carbon contents than 304L (0.03\% C maximum) would also be expected to have greater resistance. If concentrated electrolyte effects and resulting pitting/crevice corrosion develops, $316 \mathrm{~L}$ stainless steel may be the choice, as molydbenum additions are krown to combat these forms of corrosion. If the concentration effects are severe, a higher molybdenum content alloy, such as $317 \mathrm{~L}$, may be required. The low carbon content of these alloys should impart resistance to sensitization-induced corrosion effects comparable to that of 304L. If the 304L is subject to transgranular stress corrosion cracking because of high residual stress in the canister plus high chloride levels in the environment, then a high-nickel alloy, such as Alloy 825, may fill the need. As this alloy is titanium stabilized it should have resistance to sensitization-induced corrosion effects comparable to that of 321. (The high Ni content of 825 makes it more susceptible to sensitization so a higher level of $\mathrm{Ti}$ than in 321 is needed to offset this effect). As Alloy 825 contains 2.5 to $3.5 \%$ Mo, it is expected to show resistance to pitting and crevice attack at least as good as that of $316 \mathrm{~L}$. The logic in this choice of candidate materials is to proceed in a forward direction in overcoming a particular corrosion problem while not losing ground in resistance to another form of corrosion. The text by Sedricks (9) gives an expanded discussion of corrosion problems and material selection approaches to overcome these problems.

Obviously, the choice of Alloy 825 over $304 \mathrm{~L}$ would renresent a significant cost increase. Use of the stabilized grades of stainless steel requires some attention to the weld procedure (to avoid hot cracking and microfissuring) and tı.e cooling procedure (to favor titanium or niobium carbide formation over chromium carbide precipitation). While these are important considerations in materials selection for this application, their discussion is beyond the scope of this paper. 
In order to reduce the test matrix to manageabie dimensions, $304 \mathrm{~L}, 321$, $316 \mathrm{~L}$, and 825 are the alloys of concentrated interest. Premium grades of 304L (with careful control of carbon and possibly other interstitial elements: $N$, $P$, and S) will be pursued if 304L generally performs well, but test results indicate that tighter controls on the chemical composition could substantially improve the corrosion performance. The ASTM specifications for the candidate alloys is given in Table 5 .

In addition to the generally good corrosion resistance, the reference and alternative canister materials possess good fracture toughiness properties. While the canister need not be a high strength material, fracture toughness is important in the handling and emplacement operations of waste packages. A discussion of the mechanical properties of these materials relative to the requirements in a tuff repository is available (10).

\section{Overpacks and Borehole Liners}

The fabrication and welding process for making and sealing the canisters undoubtedly bears on the material selection (and vice versa). For the reprocessed waste forms ( $\mathrm{OHLW}$ and CHLW) where a borosilicate glass is poured into the canister, the times at elevated temperatures and stress distribution resulting from that operation may have a large bearing on the subsequent performance of the canister in the repository environment. There is a design option to overpack the pour canisters with another metal barrier; this option may be selected if testing reveals that the more highly stressed canister is susceptible to a localized or stress form of corrosion. As in the case of the canister, 304L stainless steel serves as the reference material for the overpack. The overpack, of course, would not be subject to the same high degree of residual stress as a canister of the same material. Spent fuel canisters are not expected to have as much residual stress as the canisters containing the reprocessed forms of nuclear waste.

In the repository, waste packages may be emplaced vertically or horizontally. Horizontal emplacement requires a borehole liner to prevent any rock dislodgment from preventing retrieval of the waste package. The retrieval period is the first 50 years of storage. Carbon steels are unfer consideration for borehole liner materials. 
After emplacement in the repository, the canister surface will experience a lengthy time at temperatures in the ringe of $100-300^{\circ} \mathrm{C}$. The time-temperature profile depends, of course, on many factors including waste form, age of waste, configuration and thermal conductivity of rock and packing material. The concern here is that during the decades at these modestly high temperatures a sensitized microstructure may develop. The prior history of the canister may influence the susceptibility to low temperature sensitization because the higher temperature processes 'not working, welding, glass pour) may set up conditions which subsequently favor carbide precipitation at a later stage even though the initial higher temperature process does not result in a recognizable sensitized structure. The low temperature sensitization of stainless steels has been discussed by Povich $(11,12)$, particularly as it applies to Type 304 stainless in the BWR environment.

While the effect of the higher temperature processes can be studied by experimental means, evaluation of the long term loiv temperature sensitization is more amenable to a calculational approach. We have begun such an effort to extend the kinetics of the various metallurgical processes to the lower temperature region. In addition to sensitization effects, per se, (that is carbide precipitation accompanied by chromium depletion near the carbide) we are also considering sigma phase formation. Sigma phase greatiy reduces the fracture toughness of stainless steel.

The detailed objectives of this study are as follows:

1) Determination of the concerns; i.e,, precipitation and diffusion processes that are detrimental to corrosion and mechanical properties.

2) Characterization of the kinetics of these processes.

3) Development of a computer model to enable simulations of the time-temperature process history and time-temperature-sensitization (TTS) relationships.

4) Evaluation of sensitization to IG corrosion and IGSCC of Type $304 \mathrm{~L}$ stainless steel (and ultimately alternative materials)! 
5) Assessment of the long-term structural stability of Type 304L (and uitimately alternative materials).

The first phase of the computer simulation model has been developed, and demonstration runs were made to simulate the sensitization of 304L stainless steel with respect to $M_{23} C_{6}$ formation. $\left(M_{23} C_{6}\right.$ represents a generis carbide stoichiometry where $M$ is the metallic atom, here principally $\mathrm{Cr}$ with some $\mathrm{Fe}$ ). The simulations were based mostly on experimental, time-temperature-sensitization data rather than actual free energy data. Classical nucleation theory was used to extrapolate the TTS curves to lawer temperatures. The results indicate a strong dependence of the time to achieve a sensitized structure on the experinental activation energies and on the assumed canister surface temperature in the repository. These preliminary results underscore the importance of knowing and/or controlling the factors which in turn influence the activation energy and canister temperature. With regard to the activation energy, the composition of the alloy and compositional differences across grain boundaries and in heat affected zones are of paramount importance.

The rate of carbide precipitation (leading to sensitization) is highly dependent on carbon content in the $600^{\circ} \mathrm{C}$ to $800^{\circ} \mathrm{C}$ range. If sensitization during welding is a major problem, this would be the region of concern. However, below $550^{\circ} \mathrm{C}$, the carbon content has very little effect on the TTS curve. Hence, the long term low temperature sensitization should not be as dependent on carbon content.

Subtle processing details, involving for example the amount, temperature, and rate of mechanical work during canister fabrication, can greatly affect the TTS curve. However, these fabrication variables and their process variation limits must be known before meaningful "TTS" simulations (weld, fill, store) can be executed. The thermal history in the welded areas, residual stresses from welding ind glass pouring, and the more severe thermal history of the pour canisters themselves are all critical issues. 
Conflicting opinions exist on the role of nitrogen in intergranular corrosion $(13,14)$. The stabilized austenitic grades provide an excellent solution to the $M_{23} C_{6}$ sensitization issue, but associated welding problems involving high temperature TiC $(\mathrm{NDC})$ dissolution and subsequent $\mathrm{M}_{23} \mathrm{C}_{6}$ formation. Extra low carbon grades are of value if sensitization (or nucleation of precipitates which might grow later) is a problem during the high temperature operations. Also, the molybdenum additions in Types 316L and $317 \mathrm{~L}$ appear to impart greater resistance to sensitization-induced corrosion effects over that of 304L; however. Mo adfitions may be detrimental with regard to enhancing sigma phase formation.

Ising activation energy values of 37-40 kcal/mole for carbon diffusion in a stainless steel lattice and a value of $67 \mathrm{kcal} / \mathrm{mole}$ for chromium diffusion, we have estimated times on the order of several hundred years before a sensitized structure would develop in 304L stainless steel. However, many uncertainties need resolution, as pointed out above. Further, at low temperatures enhanced diffusion prccesses, such as along dislocation pipes, may be of particular concern in highly cold worked areas. We are continuing our study in these areas.

\section{Welding Considerations}

The work of Hanninen (15) has shown that in welds of 304 stainless steel, residual impurities such as phosphorus and sulfur which have segregated to solidification boundaries before sensitization, will continue to diffuse toward solidification boundaries during reheating. Because the impurities are more soluble in $\delta$-ferrite than in austenite, they segregate along with cliromium and other ferritizers to the boundaries. Thus, even though carbides inay not be visible, there is a pre-existing driving force of carbide formation at solidification or cell boundaries. While these segregants could have an effect on the nucleation and growth of carbides and the kinetics of chromium depletion, it is important to realize that carbide growth at grain boundaries causes local rejection and hence enrichment of impurities. High phosphorus concentrations could enhance the susceptibility to IGSCC in a moderately oxidizing aqueous media, which is a possibility in this case. Also, these impurities can be directly oxidized into solution, thus changing local solution chemistry. 
Many investigators (16) agree that when welding 304 or $304 \mathrm{~L}$, controlling weld parameters and chemical composition will produce a crack-free, unsensitized microstructure which is highly corrosion resistant. Low temperature sensitization, i.e., at temperatures below $500^{\circ} \mathrm{C}$, continues to be a problem, especially in the heat affected zone (HAZ). Small carbides which may have nucleated in the grain boundaries, are usually not numerous enough to be damaging. Post weld exposure to temperatures as low as $250^{\circ} \mathrm{C}$ will allow carbides to grow without nucleating new carbides. Since the carbide-free material is unaffected, the weld behaves differently from the base material. Maintaining a low carbon content of course, pushes the time-temperature-sensitization (TTS) curve to the right, thus reducing the amount of carbide precipitation.

The intentional prcsence of $\delta$-ferrite in the weld microstructure to prevent cracking, can also be detrimental over long periods of time or with high temperature exposure. It has been shown that any carbides which may have grown due to low temperature sensitization will most likely reside at austenite-ferrite boundaries $(17,18)$. Residual stress from welding, coupled with a possible corrosive media could contribute to cracking along phase boundaries. 'Secondly, $\delta$-ferrite is known to transform into a hard, brittle sigma phase $(\sigma)$ when heid at elevated temperatures. Although most studies show the nucleation time of $\sigma$ phase from $\delta$-ferrite to be quite long, some $\sigma$ phase nuclei can appear in one to five minutes at $750^{\circ} \mathrm{C}(19)$. Sigma phase formation in welds of Type 18-8 steels can be delayed by balancing alloying elements. Molybdenum additions (as in 316L) have been shown to increase the tendency to sigma phase formation. Cold deformation which accelerates the formation of sigma phase, may be a concern if the canisters are fabricated from rolled steel plate. Perhaps some type of stress relief would be appropriate before welding. Rapid cooling rates during welding are of paramount importance to prevent subsequent sensitization during the glass pouring operation. For this reason, the trade-off between thin-wire, double-pass welds vs. thick-wire, single pass welds is an issue.

As regards the stabilized austenitic grades, namely 321 and 347, investigators have shown that the $\mathrm{NDC}$ and TiC can dissolve during welding. Reheating may resu?t in precipitation of $\mathrm{M}_{23} \mathrm{C}_{6}$ carbides at grain boundaries or solidification boundaries along with transgranular TiC and $\mathrm{NbC}$. 
In addition, the grain interior becomes hardened by the transgranular $\mathrm{NbC}$ and TiC, forcing the stress relaxation to occur via grain boundary sliding. With local enrichment of impurities at grain boundaries, it is not unreasonable to envision eventual cracking to accommodate high, residual stresses due to welding. Formation of the $M_{23} C_{6}$ carbides at the grain boundaries can result in "knife line" corrosion attack in oxidizing environments so that any expected benefit from the $\mathrm{Ti}$ or Nb addition has been eliminated.

\section{Experimental Test Results}

A testing program was begun in October 1982 to resolve some of the corrosion-related concerns discussed above. The test program focuses on $304 \mathrm{~L}$ stainless steel as the reference material and the other austenitic alloys as alternative materials. Some testing of carbon and alloy steels was begun as these materials may be used for borehole liners. The test environments fall into three general categories: (1) hot, "dry" air with controlled humidity levels, but well below saturation, at temperatures $95-300^{\circ} \mathrm{C}$. This environment corresponds to the initial conditions where the thermally hot waste package drives moisture away from its vicinity. (2) "Moist" air with humidity levels at or near saturation. This environment corresponds to the period when the rock has cooled to about $95^{\circ} \mathrm{C}$ and water can re-enter the vicinity of the waste package. (3) Water immersion ( $\mathrm{J}-13$ well water). This environment corresponds to possible episodic intrusions of water into the repository environment. As the DHLW waste package canister temperature reaches a "saturation" condition much sooner than the other waste packages (see Figure 2), it may encounter more severe corrosion-limiting conditions.

Emphasis was placed on environmental conditions (2) and (3), because these are believed to be more instructive in guiding the material selection process. Survey experiments were begun with $J-13$ water in contact with crushed Topopah Spring tuff and in the vapor phase over this solution. Some tests were conducted in the presence of a Co-60 source to produce gamma radiation. Test results available as of this writing (September 1983) are now discussed. 
A coupon test without irradiation is in operation. After slightly more than 1000 hours of exposure time, the first group of specimens was removed from the $100^{\circ} \mathrm{C}$ test in tuff-conditioned water and saturated steam. Water from J-13 well was conditioned by contact with crushed Topopah Spring tuff (2 $\mathrm{mm}$ average particle size). A number of differenc carbon steels, alloy steels, and stainless steels ware tested in the same cell. This would simulate cond"tions where a carbon steel (or possibly alloy steel) liner was used in conjunction with a stainless steel canister. Some ferritic stainless steels were also tested. The iron-rich soluble corrosion products from the liner may have an influence on the carrosion performance of the stainless steel. The main reason for the inclusion of the following list of steels was to observe the effect of principal alloying elements on the overall corrosion behavior of the materials. In many instances, certain of the steels would not be suitable construction materials owing to the high carbon contents in some of them and the resulting fabrication and welding difficulties they could present. Triplicate specimens were used for each alloy. Rectangular coupons were nominally 2 -inch by 1 -inch and were fitted with specially made creviced teflon washers so that incipient crevice attack could be observed. The test cell is maie of polycarbonate ind is comprised of two parts. The top part houses the specimens while the lower part contains the crushed rock. The J-13 water slowly circulates between the two parts.

The coupons were suspended so that some were immersed in the water while others were exposed to the steam phase at the top of the enclosed cell. The weight lass of each exposed coupon was determined (ASTM G-1 Test Procedure), and the coupon surfaces were examined for evidence of localized corrosion both on the creviced surface and on the freely exposed surface. The corrosion rate (in $\mu \mathrm{m} /$ year) was calculated for each individual coupon and the results are presented in Table 6 .

The results in Table 6 show, as expected, that the carbon and alloy steels corrode at rather low general rates due to rather low oxygen levels in boiling water. The general corrosion rates on the stainless steel are very sinall; many of the values were below the detection limit. The carbon and alloy steels showed some localized attack, which was most severe in the creviced region. The $9 \mathrm{Cr}-1$ Mo alloy steel behaved like the stainless steels with regard to its localized corrosion behavior. 
This test is continuing for longer exposura times. In a separate series of cells, specimens of the ieference and alternative stainless steels are being tested at different temperatures. No carbon or low alloy steels are placed in these cells.

\section{Corrosion Tests in Radiated Environments}

Tests were conducted at the Pacific Northwest Laboratory in J-13 water irradiated with a Co-60 source. Test vessels are placed at the bottom of the "gamma pit"; the radiation level is calculated from the age of the source, the location of the test vessel, and attenuation effects caused by the vesse?. These procedures are detailed elsewhere (20). Air-sparged J-13 water was flowed at a rate of $35 \mathrm{ml} / \mathrm{hr}$ through the test vessels. Crushed Topopah Spring tuff was placed in the bottom of each vessel so that some test specimens could be embedded in this rock + water environment in an effort to accentuate "crevice effects" around the coupon. One test vessel was maintained at $105^{\circ} \mathrm{C}$ (under pressure) and the salculated radiation dose rate in the center of this vessel was $3 \times 10^{5} \mathrm{rads} / \mathrm{hr}$; the other test vessel was maintained at $150^{\circ} \mathrm{C}$ with a radiation rate dose of $6 \times 10^{5} \mathrm{rads} / \mathrm{hr}$. (For comparison, the estimated maximum dose rate at the canister surface for a CHLW waste package is $1 \times 10^{5} \mathrm{rads} / \mathrm{hr}$.) 1025 wrought steel, $9 \mathrm{Cr}-1$ Mo alloy steel, and 304L stainless steel were tested. The $304 \mathrm{~L}$ coupons were solution annealed $\left(1050^{\circ} \mathrm{C}\right.$ for 15 minutes and water quenched), and some coupons were subsequently given a treatment in the usual sensitization range $\left(600^{\circ} \mathrm{C}\right.$ for 10 hours and air cooled). The test results for the individual coupons are presented in Table 7.

Comparison of these data with those in Table 6 (non-irradiated) indicates that the carbon steel (1020 vs $1025 ; 100$ vs $105 \mathrm{C}$ ) is rather unaffected by radiation. Two of the 1025 specimens at $150^{\circ} \mathrm{C}$ corroded at considerably higher rates than the others, however. The $9 \mathrm{Cr}-1$ Mo alloy steel appears to be susceptible to the radiated aqueous environment, as its corrosion rate $r$ ises substantially over comparable rates in non-radiated $\mathrm{J}-13$ water. The beginning of localized attack was observed on the surfaces of the $9 \mathrm{Cr}-1$ Mo alloy steel specimens embedded in the crushed tuff at both 105 and $150^{\circ} \mathrm{C}$. The 304L stainiess steel showed a general corrosion rate increase when 
irradiated, and the specimens given the "sensitizing" treatment suffered additional corrosion at the higher temperature. However, no indication of preferential intergranular attack was observed on these coupons, but additional exposure time is required before definitive conculsions can be drawn. All the corrosion penetration rate data for $304 \mathrm{~L}$ stainless steel were less than $0.02 \mathrm{mils} / \mathrm{yr}(0.5 \mathrm{jm} / \mathrm{yr})$.

\section{Stress Corrosion Test Resu1ts}

For purposes of survey tests to indicate which combinations of environments and alloy compositions/metallurgical conditions lead to stress corrosion susceptibility, both the "slow strain rate" test and four-point loaded bent beam configuration are used. Some results from the slow strain rate tests are available and are summarized in Table 8 . Type $304 \mathrm{~L}$ specimens are tested in both the solution annealed and in the "sensitized" conditions. Solution annealing was performed at $1050^{\circ} \mathrm{C}$ for 15 minutes followed by a water quench. The sensitizing condition was affected from the solution annealed condition by a subsequent heat treatment at $600^{\circ} \mathrm{C}$. for 10 hours followed by an air cool. Note that these times and temperatures are representative of the reprocessed glass waste pouring operation into a stainless steel canister; they should readily sensitize the higher carbon 304 stainless steel. The actual carbon level in the tested steel was $0.024 \%$. No discernible sensitization occurred in the 304L as indicated by ASTM A262 Practice $A$ and $E$ tests, however. The slow strain rate tests were conducted at $10^{-4}$ and $2 \times 10^{-7} \mathrm{sec}^{-1}$ and at $150^{\circ} \mathrm{C}$ in air-sparged tuff-conditioned J-13 water. The water circulated slowly between the test vessel and another vessel holding crushed Topopah Spring tuff rock. The initial tests were conducted at $150^{\circ} \mathrm{C}$ to accelerate any stress corrosion susceptibilities. However, the limited number of results in Table 8 indicate that neither metallurgical condition and neither strain rate provoked stress corrosion effects. All fractures were ductile. Tests are continuing at other temperatures and strain rates.

Four-point load bent-beam specimens (ASTM G-39 test procedure) are being exposed in $3-13$ tuff-conditioned water at $100^{\circ} \mathrm{C}$ with some specimens being suspended in the saturated vapor space in the test cell. Specimens of 304 , $304 \mathrm{~L}, 316 \mathrm{~L}$, and 321 are stressed to $90 \%$ of their yield stress. Type 304 
stainless steel was added to the test matrix in an attempt to produce an early failure and prove the test validity. These specimens are in the solution annealed, cold-worked, and furnace sensitized conditions (some treated at $700^{\circ} \mathrm{C}$ for 10 minutes, water quenched; others, at $550^{\circ} \mathrm{C}$ for 24 hours, air cool). Some specimens are cold worked and then furnace sensitized. Other specimens contain welds which are produced by a gas-metal-arc (GMA) process (hand-held wire feed; double-pass; gas mixture of $\mathrm{Ar}$, $\mathrm{He}, \mathrm{CO}_{2}$ ). The specimen/weld wire combinations are 304/308; 304L/308L; 316/316L; 321/347. These stress corrosion tests are now underway.

\section{Electrochemical Polarization Test Results}

Electrochemical polarization testing of the reference and alternative canister materials complements the corrosion coupon testing. Three different techniques are ised: (1) Linear polarization resistance, where the potential is scanned $\pm 10 \mathrm{mv}$ from the corrosion potential and the corresponding corrosion current is calculated from the polarization resistance; (2) Tafel slope extrapolation, where the potential is scanned several hundreds of millivolts in both the cathodic and anodic directions, and the corrosion current is calculated from the respective slopes of each direction; and (3) Cyclic anodic polarization scanning, where the potential is scanned in the anodic direction until breakdown of the passive film occurs, then the direction of the scan is reversed. The hysteresis of the forward and backward scan is indicative of the susceptibility of the alloy/environment combination to pitting and crevice corrosion. These techniques have been described, among other places, in the collection of 1976 symposium papers (21). In the present work, a Princeton Applied Research 350 Unit was used, a scan rate of $1 \mathrm{mv} / \mathrm{sec}$ was used for all work reported here, and the exposed sample area was $1 \mathrm{~cm}^{2}$. The alloys were in the annealed condition, and the initial surface preparation was 400 grit finish, degrease in acetone, water rinse.

Representative values of the corrosion current densities are shown in Figures 3 and 4 for both the linear polarization and Tafel extrapolation methods and for a number of candidate alloy materials. Figure 3 indicates ${ }^{i}$ corr as determined on a freshly prepared surface and Figure 4 indicates

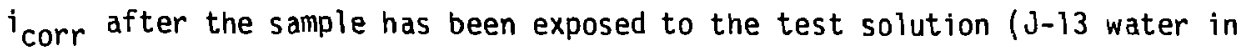


contact with crushed tuff rock) for 500 hours. There is considerable spread in the data between replicated runs and between the two techniques. The values of $i_{\text {corr }}$ calculated from Tafel slope extrapolation are usually smaller than the corresponding linear polarization resistance values. The electrochemical pelarization results generally show higher corrosion rates than the weight loss coupons for the alloys which were tested in both kinds of tests (see Table 6). The results obtained for the electrochemical tests after 500 hours of exposure to the test solution are more consistent with one another. In general, the corrosion rate shows a small decrease with exposure time.

Corrosion potentials and the so-called protection potential are plotted in Figures 5-8 for the different candidate alloys in J-13 water again in contact with crushed tuff rock. The protection potential is the potential at which the current goes effectively to zero on the reverse scan. Pits would not initiate, and pre-existing pits would not propagate at potentials below this value. The main comparison is the position of the protection potential relative to the corrosion potential. When $E_{\text {prot }}$ is considerably more noble than the $E_{\text {corr }}$, then the alloy is not expected to be susceptible to pitting corrosion under the environmental conditions of the test. The prediction of crevice corrosion is not as straightforward, although the relative position of the two potentials is indicative of the crevice corrosion resistance of the alloy. The results given in Figures 5-8 indicate that the candidate alloys are resistant to pitting corrosion in $\mathrm{J}-13$ water in the $50-100^{\circ} \mathrm{C}$ temperature range, as the Erot values are all at least $180 \mathrm{mv}$ more noble than the corresponding value of $E_{\text {corr }}$. The spread between the two potentials appears to increase with the alloying content, being the least for 304L (Figure 5) and the greatest for alloy 825 (Figure 8 ), as expected. These results are consistent with the results from the limited amount of coupon testing completed so far. Work continues in this area to test in solutions more concentrated in the species present in $\mathrm{J}-13$ water. Also work is underway to test in simulated radiolys is conditions where the more stable species which may be produced by radiolysis of the solution are intentionally added to the test solution. These species include hydrogen peroxide and nitrate ion. 
All of the results to date indicate that $304 \mathrm{~L}$ stainless steel performs suitably as a containment material under the environmental conditions tested, but much more testing is required before definitive conclusions can be ćrawn. The very limited number of corrosion test results confirms earlier predictions of generalized corrosion behavior. As localized corrosion (intergranular, pitting, crevice) and stress corrosion cracking concerns are more restrictive in the use of 304L (and other austenitic alloys), these forms of corrosion attack are addressed more thoroughly in future work. The work so far has proceeded according to the premise that Tr.- Jpah Spring tuff (collected from outcroppings) and J-13 water are representative of the geochemical environment of the repository in Yucca Mountain. When the exploratory shaft is si intn the mountain (expected in late 1985), rock and water samples from the acs d repository environment will then be obtained and in situ field tests will be performed. In the meanwhile, work will progress in bracketing the response of the candidate alloys to the expected environmental conditions at Yucca Mountain, as well as to possible episodic environmental conditions. These tests will provide an important part of the data base from which the inal selection of materials and fabrication processes will be specified and on which the models for extrapolation to long term corrosion behavior will be based. Special attention is being paid to the effects of the fabrication, welding, glass pour, and handling processes on the ultimate chemical stability of the canister in the repository.

\section{Acknowledgments}

It is a pleasure to thank many other people whose efforts have added to the successful beginning of this project. R. E. Garrison and S. C. Aceves performed most of the experimental work at this Laboratory. The "slow strain rate" and many of the radiation experiments were conducted at Battelle's Pacific Northwest Laboratories. We thank R. E. Westerman, S. G. Pittman, and J. M. Nelson of that organization for their contributions. J. L. Younker and R. A. Van Konynenburg reviewed the manuscript for this paper, while $L$. $B$. Ballou and V. M. Oversby provided overall guidance for the nuclear waste package project. 


\section{REFERENCES}

1. Westinghouse Electric Corp., "Conceptuai Waste Package Designs for Disposal Waste in Tuff," AESD-TME-3138 (December 1982).

2. J. K. Johnstone and K. Wolfsberg, editors, "Evaluation of Tuff as a Medium for a Nucleur Waste Repository: Interim Status Report on the Properties of Tuff," Sandia National Laboratories, SANDB0-1:.64 (July, 1981).

3. W. W. Dudley and B. R. Erda1, "Site Characterization for Evaluation of Potential Nuclear Waste Isolation at Yucca Mountain, Nevada," Proceedings of the 1982 National Waste Terminal Storage Program Information Meeting, p. 10, D0E/NWTS-30, (December 1982).

4. V. M. Oversby, "Description of Reference Waste Form and Backfill Materials for the NNWSI Prograil," Lawrence Livermore National Laboratory, report in preparation, (1983).

5. R. G. Baxter, "Description of DHLW Reference Waste Form and Canister," E.I. Du Pont de Nemours \& Co., Savarnah River Laboratory report [P-1601 (1981).

6. Y. M. Oversby, "Reaction of Crushed Topopah Spring Tuff with 3-13 Water," Lawrence Livermore National Laboratory, report in preparation (1983).

7. F. L. LaQue and H. R. Copson, editors, Corrosion Resistance of Metals and Alloys, second edition, Chapter 15, Reinhold Publishing Co., New York (1963).

8. K. Nuttali and V. F. Urhanic, "An Assessment of Materials for Nuclear Fuel Immobilization Containers," Atomic Energy of Canada, Ltd., report AECL-6440 (September 1981).

9. A. John Sedricks, Corrosion of Stainless Steels, Chapter 2, John Wiley \& Sons, New York (1979). 
10. E. W. Russe11, R. D. McCright, and W. C. O'Neal, "Containment Barriers for" High-Level Waste Packages in Tuff, "Lawrence Livermore National Laboratory, report UCRL 89404 (September 1983).

11. M. J. Povich, "Low Temperature Sensitization of Stainless Stee1," Corrosion, vol 34, p. 60 (February 1978).

12. M. J. Povich and P. Rao, "Low Temperature Sensitization of Welded Type 304 Stainless Steel," Corrosion, vol 34, p. 269 (August 1978).

13. G. M. Gordon, "Physical Metallurgy of Fe-Cr-Ni Alloys," Proceedings of Conference: Stress Corrosion Cracking and Hyárogen Embrittlement of Iron-Base Alloys," NACE-5, p. 843, Houston (1977).

14. R. A. Mulford, E. L. Hal1, and C. L. Briant, "Sensitization of Austenitic Stainless Stees, Commercial Purity Alloys," Corrosion, vol 39, p. 132 (Apri1 1983).

15. H. Hanninen, "Grain Boundary Segregation in Austenitic Stainless Steels," Technical Research Center of Finland, Research Reports, 32!1981 (1981).

16. H. D. Solomon, "Embrittlement of Welds," G.E. Technical Report, 82CR0182 (August 1982).

17. C. DaCasa, V. B. Nileshwar, and D. A. Melford, ${ }^{M} M_{23} C_{6}$ Precipitation in Unstabilized Austenitic Stainless Steel," Journal of the Iron and Steel institute, p. 1325 (0ctober 1969).

18. P. Duhaj, J. Ivan, and F. Makovicky, "Sigma Phase Precipitation in Austenitic Steels," Journal of the Iron and Steel Institute, p. 1245 (December 1968).

19. J. Wegrzyn and $A . K 1$ impel, "The Effects of Alloying Elements on Sigma Phase Formation in 18-8 Weld Metals," Welding Journal, p. 146-S (August 1981). 
20. R. E. Westerman, S. G. Pitman, and J. L. Nelson, "General Corrosion, Irradiation Corrosion and Environmental-Mechanical Evaluation of Nuclear Waste Package Structural Barrier Materials, Pacific Northwest Laboratories report PNL-4364 (1982).

21. R. Baboian, editor, Electrochemical Techniques for Corrosion, NACE, Houston (1977). 
Table 1. Major Element Bulk Composition for Reference Welded Tuff

$\begin{array}{ll}\mathrm{SiO}_{2} & \begin{array}{c}\text { Typical } \\ \text { Range } \\ \text { (wt } \%)\end{array} \\ \mathrm{TiO}_{2} & 68-75 \\ \mathrm{Al}_{2} \mathrm{O}_{3} & 0.0-0.4 \\ \mathrm{Fe}_{2} \mathrm{O}_{3} & 10-17 \\ \mathrm{FeO}^{2} & 0.1-2.0 \\ \mathrm{MnO} & 0.1-2.0 \\ \mathrm{MgO} & 0.0-0.2 \\ \mathrm{CaO}^{2} & 0.1-1.5 \\ \mathrm{Na}_{2} \mathrm{O} & 0.5-2.5 \\ \mathrm{~K}_{2} \mathrm{O} & 1.0-6.0 \\ \mathrm{P}_{2} \mathrm{O}_{5} & 2.0-7.0 \\ \mathrm{~S} & 0.0-0.2 \\ \mathrm{H}_{2} \mathrm{O} & 0.0-2.0 \\ & 1.0-5.0\end{array}$


Table 2 Reference Groundwater Composition for Tuff Repositories (Based on Composition of Jackass Flats Well J-13 at the Nevada Test Site)

\section{Concentration \\ (mg/liter)}

$\begin{array}{lc}\text { Lithium } & 0.05 \\ \text { Sodium } & 51.0 \\ \text { Potassium } & 4.9 \\ \text { Magnesium } & 2.1 \\ \text { Calcium } & 14.0 \\ \text { Strontium } & 0.05 \\ \text { Barium } & 0.003 \\ \text { Iron } & 0.04 \\ \text { Aluminum } & 0.03 \\ \text { Silica } & 61.0 \\ \text { Fluoride } & 2.2 \\ \text { Chloride } & 7.5 \\ \text { Carbonate } & 0.0 \\ \text { Bicarbonate } & 20.0 \\ \text { Sulfate } & 22.0 \\ \text { Nitrate } & 5.6 \\ \text { Phosphate } & 0.12\end{array}$

$\mathrm{pH}$ - slightly basic (7.1) 
Table 3 Dimensions and Power Load Outputs for Reference Waste Packages

\begin{tabular}{|c|c|c|c|c|}
\hline $\begin{array}{c}\text { Waste } \\
\text { Package }\end{array}$ & $\begin{array}{c}\text { Canister } \star \star \\
\text { Outer } \\
\text { Diameter } \\
(\mathrm{cm}) \\
\end{array}$ & $\begin{array}{l}\text { Waste } \\
\text { Length } \\
(\mathrm{cm}) \\
\end{array}$ & $\begin{array}{c}\text { Canister } \\
\text { Length } \\
\text { (cm) }\end{array}$ & $\begin{array}{l}10 \mathrm{yr} \\
\text { old } \\
\text { Power } \\
\text { Load (kw) } \\
\end{array}$ \\
\hline CHLW & 32.0 & 264 & 300 & 2.21 \\
\hline DHLW & 61.0 & 231 & 300 & 0.42 \\
\hline S.F.-BWR & 57.0 & 413.7 & $450^{*}$ & 3.42 \\
\hline S.F. -PWR & 50.0 & 410.6 & $450 *$ & 3.30 \\
\hline
\end{tabular}

* length $=(1.05 \times$ Fuel Rod length $)+$ pintle length of $16.5 \mathrm{~cm}$.

** assumed canister wall thickness is $9.8 \pm 0.3 \mathrm{~mm}$. 
Table 4 Experimental Data Indicating Water Chemistry For A Repository in the Topopah Spring Tuff

Expected High-Temperature Composition

Based on J-73 Reacted with Topopah Spring Tuff

Species

\begin{tabular}{l}
$150^{\circ} \mathrm{C} \quad 90^{\circ} \mathrm{C}$ \\
Concentration $(\mathrm{mg} / \mathrm{L})$ \\
\hline
\end{tabular}

Si

$80 \quad 40$

$\mathrm{Na}$

$40 \quad 40$

K

9

8

B

0.1

0.12

$\mathrm{Ca}$

3

8

$\mathrm{Mg}$

0.1

0.1

$\mathrm{Fe}$

0.0 :

0.01

A1

1.5

0.5

$\mathrm{F}^{-}$

2

2

$\mathrm{Cl}^{-}$

7

7

$\mathrm{NO}_{3}^{-}$

9

10

$\mathrm{HCO}_{3}^{-}+\mathrm{CO}_{3}^{=}$

18

17

$\mathrm{pH}$

80

90

9

8.5 
TABLE 5

ALLOY COMPOSITION FOR REFERENCE AND ALTERNATIVE CANISTER

AND OVERPACK MATERIALS

Chemical Composition (weight per cent)

\begin{tabular}{|c|c|c|c|c|c|c|c|c|c|}
\hline $\begin{array}{l}\text { Cominon Alloy } \\
\text { Designations }\end{array}$ & $\begin{array}{c}\text { UNS* } \\
\text { Designation } \\
\end{array}$ & $\begin{array}{l}\text { Carbon } \\
(\max .) \\
\end{array}$ & $\begin{array}{c}\text { Manganese } \\
(\max .) \\
\end{array}$ & $\begin{array}{c}\text { Phosphorus } \\
(\max .) \\
\end{array}$ & $\begin{array}{l}\text { Sulfur } \\
(\max .)\end{array}$ & $\begin{array}{l}\text { Silicon } \\
(\max .) \\
\end{array}$ & $\begin{array}{c}\text { Chromium } \\
\text { (range) } \\
\end{array}$ & $\begin{array}{l}\text { Nickel } \\
\text { (range) }\end{array}$ & $\begin{array}{l}\text { Other } \\
\text { Elements }\end{array}$ \\
\hline $304 L$ & $\$ 30403$ & 0.030 & 2.00 & 0.045 & 0.030 & 1.00 & $18.00-20.00$ & $8.00-12.00$ & $N: 0.10 \max$ \\
\hline $316 \mathrm{~L}$ & $\$ 31603$ & 0.030 & 2.00 & 0.045 & 0.030 & 1.00 & $16.00-18.00$ & $10.00-14.00$ & $\begin{array}{l}\text { Mo: } 2.00-3.00 \\
N: 0.10 \max \end{array}$ \\
\hline 321 & S31200 & 0.08 & 2.00 & 0.045 & 0.030 & 1.00 & $17.00-19.00$ & $9.00-12.00$ & $T i: 5 \times C \min$ \\
\hline 825 & N08825 & 0.05 & 1.0 & $\begin{array}{l}\text { not } \\
\text { specified }\end{array}$ & 0.03 & 0.5 & $19.5-23.5$ & $38.0-46.0$ & $\begin{array}{l}\text { Mo: } 2.5-3.5 \\
T i: 0.6-1.2 \\
\text { Cu: } 1.5-3.0 \\
\mathrm{Al}: 0.2 \text { max }\end{array}$ \\
\hline
\end{tabular}

(Information adapted from ASTM specifications A-167, B-424, refer to ASTM Annual Book of Standrads, ASTM, Philidelphia (1982)

Note: Other stainless alloys mentioned in text: $317 \mathrm{~L}$ is similar to $316 \mathrm{~L}$ but with the Mo content increased to 3. $10-4.00$ and the $\mathrm{Cr}$ levels adjusted to $18.0 \mathrm{~J}-20.00$ and the $\mathrm{Ni}$ levels to $11.00-15.00$. 347 is a niobium stabilized stainless steel otherwise similar to 321 . Nb content is specified as $10 \times C$ content.

* Unified Numbering System for Metals and Alloys. Society of Automotive Engineers, Inc. Putilication SAE HSIU86a, WarrendaTe, PA (1977) 
TABLE 6 Corrosion Test Results for Different Steel Coupons Exposed to $100^{\circ} \mathrm{C}$ Tuff-Conditioned Water and Steam 1000-hour Exposure of Triplicate Coupons

\begin{tabular}{|c|c|c|c|c|}
\hline \multirow[t]{2}{*}{ Material } & \multicolumn{2}{|c|}{$100^{\circ} \mathrm{C}$ Saturated Steam Atmospheric Pressure } & \multicolumn{2}{|c|}{$\begin{array}{c}100^{\circ} \mathrm{C} \mathrm{J}-13 \text { water Conditioned with } \\
\text { Crushed Tuff Rock }\end{array}$} \\
\hline & $\begin{array}{l}\text { Corrosion Rates } \\
(\mu \mathrm{m} / \mathrm{yr})\end{array}$ & $\begin{array}{l}\text { Surface Condition } \\
\text { after Exposure }\end{array}$ & $\begin{array}{l}\text { Corrosion Rates } \\
(\mu \mathrm{m} / \mathrm{yr})\end{array}$ & $\begin{array}{c}\text { Surface Condition } \\
\text { after Exposure }\end{array}$ \\
\hline
\end{tabular}

\begin{tabular}{|c|c|c|c|c|}
\hline $\begin{array}{l}\text { C1020 } \\
\text { carbon stee }]\end{array}$ & $\begin{array}{l}43.43 ; 41.66 \\
60.20\end{array}$ & $\begin{array}{l}\text { Attack in all } 12 \\
\text { crevices**; localized } \\
\text { attack elsewhere }\end{array}$ & $\begin{array}{l}23.37 ; 29.97 \\
31.73\end{array}$ & $\begin{array}{l}\text { Attack in all } 12 \text { crevices } \\
\text { some light localized atta } \\
\text { elsewhere }\end{array}$ \\
\hline $\begin{array}{l}\text { A36 } \\
\text { carbon stee } 1\end{array}$ & $\begin{array}{l}42.67 ; 46.48 \\
58.42\end{array}$ & $\begin{array}{l}\text { Attack in } 5 \text { crevices; much } \\
\text { localized attack elsewhere }\end{array}$ & $\begin{array}{l}32.77 ; 39.35 \\
36.83\end{array}$ & $\begin{array}{l}\text { Attack in } 9 \text { crevices; som } \\
\text { localized attack elsewher }\end{array}$ \\
\hline $\begin{array}{l}\text { A366 } \\
\text { carbon steel }\end{array}$ & $\begin{array}{l}40.39 ; 52.07 ; \\
62.74\end{array}$ & $\begin{array}{l}\text { Light attack in } 7 \text { crevices; } \\
\text { much localized attack } \\
\text { elsewhere }\end{array}$ & $\begin{array}{l}25.65 ; 30.73 \\
27.94\end{array}$ & $\begin{array}{l}\text { Attack in all } 12 \text { crevices } \\
\text { very } 7 \text { ight localized attad } \\
\text { elsewhere }\end{array}$ \\
\hline $\begin{array}{l}2.25 \mathrm{Cr}-1 \mathrm{Mo} \\
\text { alloy steel }\end{array}$ & $\begin{array}{l}7.87 ; 12.45 ; \\
15.49\end{array}$ & $\begin{array}{l}\text { Attack in } 7 \text { crevices; some } \\
\text { localized attack elsewhere }\end{array}$ & $\begin{array}{l}29.21 ; 29.97 \\
31.75\end{array}$ & $\begin{array}{l}\text { Attack in all } 12 \text { crevices } \\
\text { considerable localized at } \\
\text { elsewhere }\end{array}$ \\
\hline $\begin{array}{l}9 \mathrm{Cr}-1 \mathrm{Mo} \\
\text { a)loy steel }\end{array}$ & $1.52 ; 1.78 ; 1.02$ & $\begin{array}{l}\text { No evidence of crevice or } \\
\text { other localized attack }\end{array}$ & $4.06 ; 3.05 ; 3.30$ & $\begin{array}{l}\text { No evidence of crevice or } \\
\text { other localized attack }\end{array}$ \\
\hline $\begin{array}{l}409 \text { stainless } \\
\text { stee } 1\end{array}$ & nil*; nil; nil & $\begin{array}{l}\text { No evidence of crevice or } \\
\text { other localized attack }\end{array}$ & nil; nil; nil & $\begin{array}{l}\text { No evidence of crevice or } \\
\text { other localized attack }\end{array}$ \\
\hline $\begin{array}{l}416 \text { stainless } \\
\text { steel }\end{array}$ & nil; $0.25 ; 0.25$ & $\begin{array}{l}\text { No evidence of crevice or } \\
\text { other localized attack }\end{array}$ & $0.25 ; 0.25 ; 0.25$ & $\begin{array}{l}\text { No evidence of crevice or } \\
\text { other localized attack }\end{array}$ \\
\hline $\begin{array}{l}\text { 304L stainless } \\
\text { steel }\end{array}$ & nil; 0.25 ; nil & $\begin{array}{l}\text { No evidence of crevice or } \\
\text { other localized attack }\end{array}$ & $\mathrm{nil} ; 0.25 ; \mathrm{nil}$ & $\begin{array}{l}\text { No evidence of crevice or } \\
\text { other localized attack }\end{array}$ \\
\hline $\begin{array}{l}316 \mathrm{~L} \text { stainless } \\
\text { stee }\end{array}$ & ni1; nil; nil & $\begin{array}{l}\text { No evidence of crevice or } \\
\text { other localized attack }\end{array}$ & $0.51 ; 0.51 ; 0.51$ & $\begin{array}{l}\text { No evidence of crevice or } \\
\text { other localized attack }\end{array}$ \\
\hline $\begin{array}{l}\text { 317L stainless } \\
\text { steel }\end{array}$ & $0.25 ; n i 1 ; 0.13$ & $\begin{array}{l}\text { No evidence of crevice or } \\
\text { other localized attack }\end{array}$ & $0.25 ; 0.51 ; 0.76$ & $\begin{array}{l}\text { No evidence of crevice or } \\
\text { other local jzed attack }\end{array}$ \\
\hline
\end{tabular}

$\star n i 1$ is less than 0.13 um/year, which is based on our weight loss detection limit.

$\star \star$ The creviced washers contain 12 separated slots. 
Table 7 Corrosion Test Results for Carbon, Alloy and Stainless Steel Coupons in Radiated Environments (2-month Exposure Data)

Material

Environment

Corrosion Penetration Rate ( $\mu \mathrm{m} / \mathrm{yr})$

\begin{tabular}{cc}
$105^{\circ} \mathrm{C}(\mathrm{a})$ & $150^{\circ} \mathrm{C}(\mathrm{b})$ \\
$3 \times 10^{5} \mathrm{rads} / \mathrm{hr}$ & $6 \times 10^{5} \mathrm{rads} / \mathrm{hr}$ \\
\hline
\end{tabular}

C1025

J-13 water $34 ; 37 ; 36 ; 36 ; 36$

Avg: 36

$3-13+$ tuff

$36 ; 57 ; 63 ; 36 ; 51$

Avg: 47

$9 \mathrm{Cr}-1 \mathrm{Mo}$

J-13 water

$3-13+$ tuff

$304 \mathrm{~L}$

(Solution annealed)

J-13 water

J-13+tuff

J-13 water

$304 L$ (solution

$J-13+$ tuff

sizing" condition)
$0.23 ; 0.37$

0.51

$14 ; 16 ; 14 ; 13 ; 15 ; 17$

Avg: 15

$20 ; 20 ; 21 ; 22 ; 21 ; 23$

Avg: 21

$0.31 ; 0.31$

0.36

$0.29 ; 0.32$

0.31

$0.25 ; 0.30$

0.55
$107 ; 23 ; 20 ; 126 ; 18 ; 16 ; 18$

Avg: 47

$45 ; 41 ; 35 ; 34 ; 35$

Avg: 38

$13 ; 14 ; 11 ; 13 ; 9.7 ; 11 ; 16$

Avg: 13

$41 ; 30 ; 32 ; 26 ; 23 ; 50 ; 38$

Avg: 34

(a) Tests conducted in Inconel 600 vessel.

(b) Tests conducted in Titanium - Grade 2 vessel. 
Table 8 Slow Strain Rate Test Results for 304L Stainless Steel in $150^{\circ} \mathrm{C}$ Tuff-Conditioned J-13 Water

\begin{tabular}{|c|c|c|c|c|c|c|c|}
\hline $\begin{array}{c}\text { Metallurgical } \\
\text { Condition }\end{array}$ & Environment & $\begin{array}{l}\text { Strain Rate } \\
\left(\sec ^{-1}\right)\end{array}$ & $\underset{(\mathscr{f})}{\text { Elongation }}$ & $\begin{array}{l}\text { Reduction } \\
\text { in Area }(\%)\end{array}$ & $\begin{array}{l}\text { Yield Stress } \\
\text { (ksi) }\end{array}$ & $\begin{array}{l}\text { Ultimate } \\
\text { Tensile } \\
\text { Stress (ksi) } \\
\end{array}$ & Comments \\
\hline$S A^{(a)}$ & $J-13$ & $10^{-4}$ & 54.0 & 80.5 & 25.8 & 68.4 & \multirow{2}{*}{$\begin{array}{l}\text { replicate tests } \\
\text { ductile fractures }\end{array}$} \\
\hline$S A$ & $J-13$ & $10^{-4}$ & 52.0 & 78.4 & 27.1 & 68.2 & \\
\hline$S A+S^{(b)}$ & $J-13$ & $10^{-4}$ & 49.6 & 72.2 & - & -- & \multirow{2}{*}{$\begin{array}{l}\text { replicate tests } \\
\text { ductile fractures }\end{array}$} \\
\hline$S A+S$ & $J-13$ & $10^{-4}$ & 51.9 & 74.8 & 29.6 & 69.1 & \\
\hline$S A+S$ & air & $10^{-4}$ & 49.0 & 73.7 & 29.4 & 68.6 & \\
\hline$S A+S$ & $J-13$ & $2 \times 10^{-7}$ & 49.0 & 76.0 & 26.6 & 68.8 & \multirow{2}{*}{$\begin{array}{l}\text { replicate tests } \\
\text { ductile fractures }\end{array}$} \\
\hline$S A+S$ & $J-13$ & $2 \times 10^{-7}$ & 48.0 & 70.4 & 27.2 & 68.6 & \\
\hline
\end{tabular}

(a) $\mathrm{SA}=$ Solution annealed $\left(1050^{\circ} \mathrm{C}, 15\right.$ minutes; water quench)

(b) $\mathrm{SA}+\mathrm{S}=$ Solution Annealed + "sensitizing" treatment (as above, then $600^{\circ} \mathrm{C}, 10$ hours, air cool) 


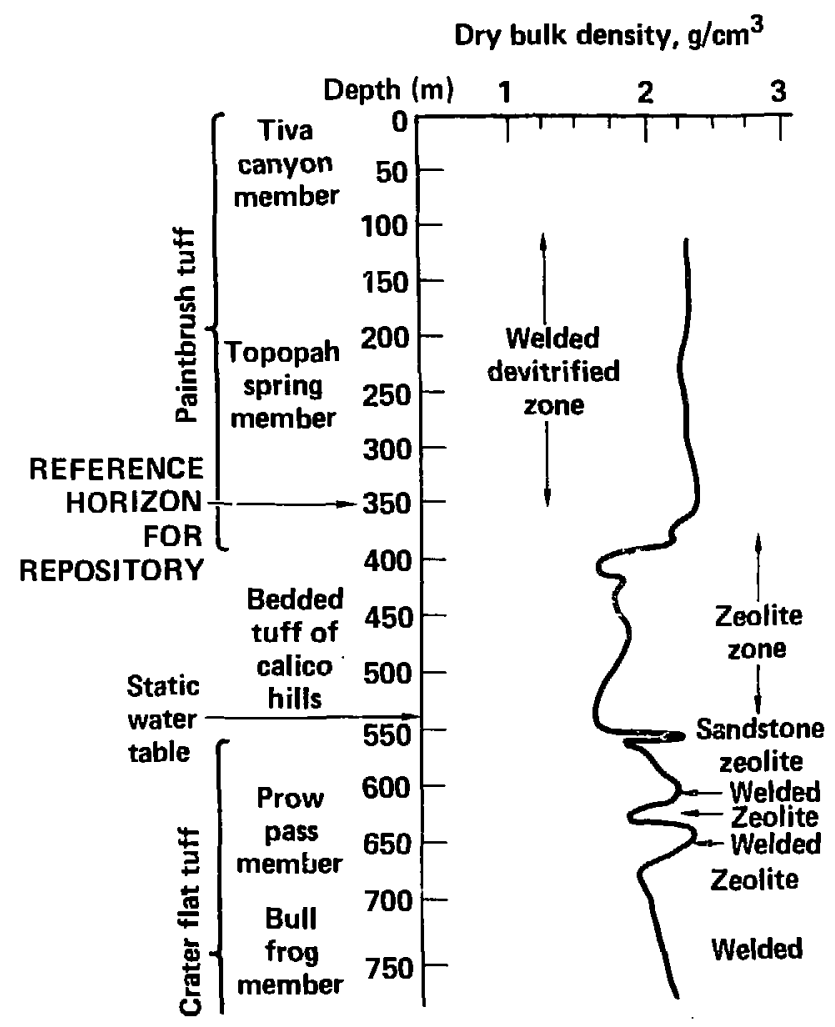

(Drillhole UE 25 a-1)

Figure 1 Representative Stratigraphic Section in Nevada Tuff (Drillhole UE 25 a-1) 


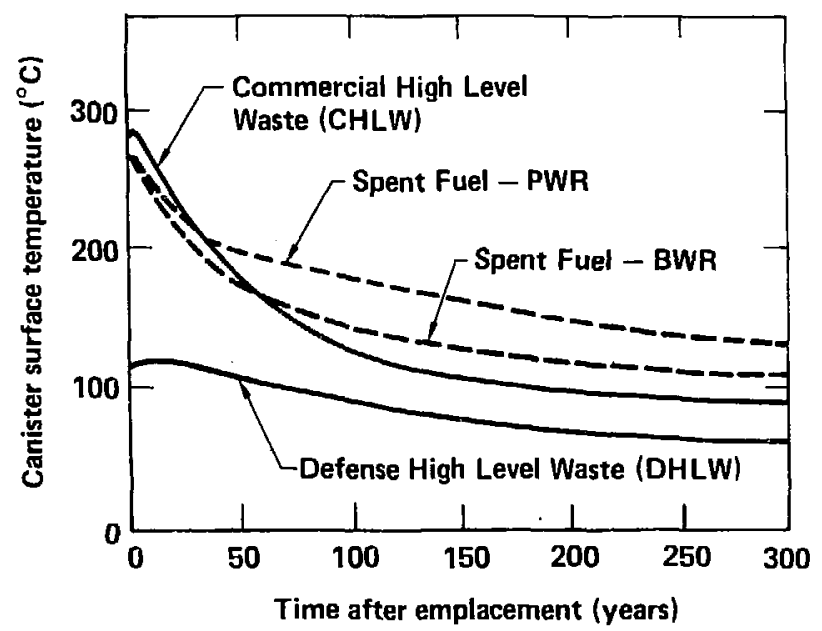

Figure 2. Comparative Canister Surface Temperature-Time Profiles for Different Waste Packages in a Tuff Repository (Vertical Emplacement, $50 \mathrm{~kW} / \mathrm{acre}$ Areal Loading, Dimensions Given in Table 3) 


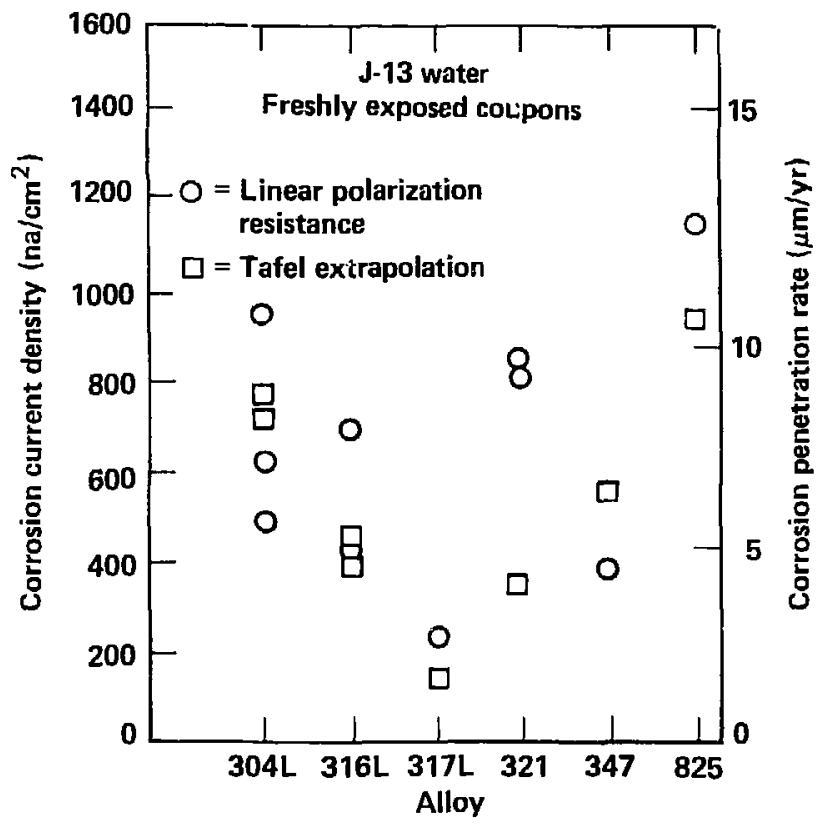

Figure 3 Electrochemical Determinations of Corrosion Rates for Different Alloys in Tuff-Conditioned J-13 Water at $100^{\circ} \mathrm{C}$ (Freshly Exposed Coupons) 


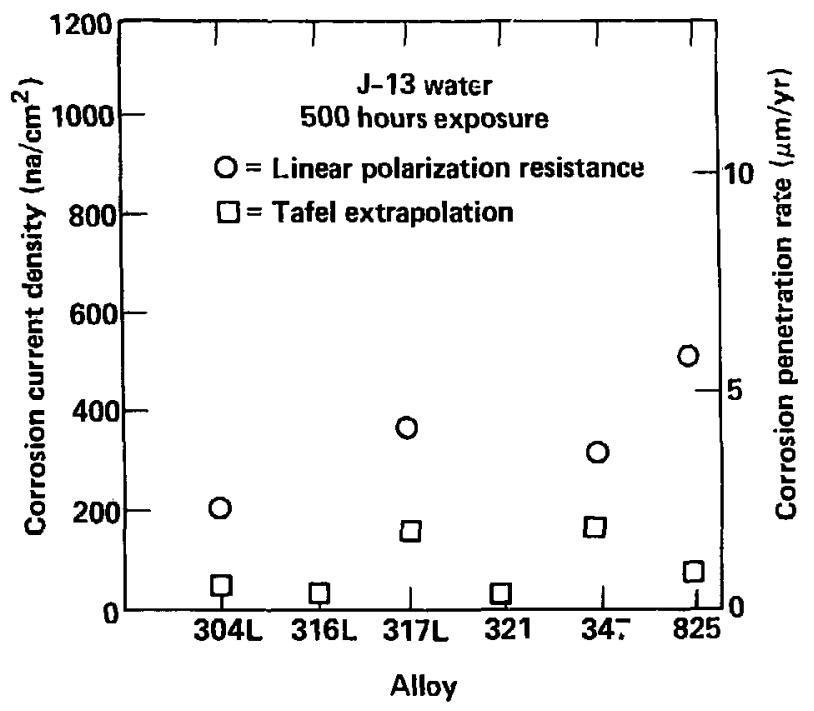

Figure 4 Electrochemical Determination of Corrosion Rates for Different Alloys in Tuff-Conditioned J-13 Water at $100^{\circ} \mathrm{C}$ (Coupons Previousty Exposed to this Environinent for 500 Hours) 


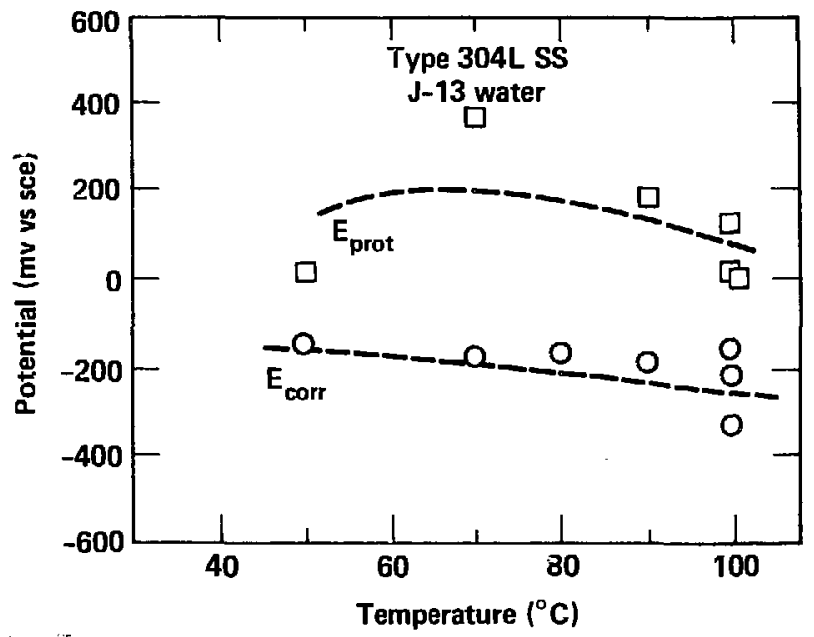

Figure 5 Corrosion Potentials and Protection Potentials for 304L Stainless Steel in Tuff-Conditioned J-13 Water at Different Temperatures 


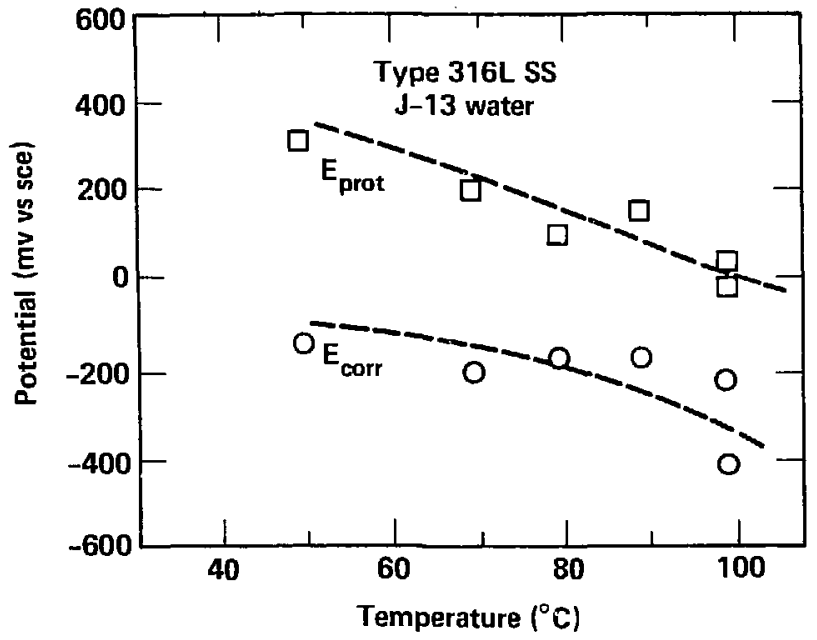

Figure 6 Corrosion Potentials and Protection Potentials for 316L Stainless Steel in Tuff-Conditioned J-13 Water at Different Temperatures 


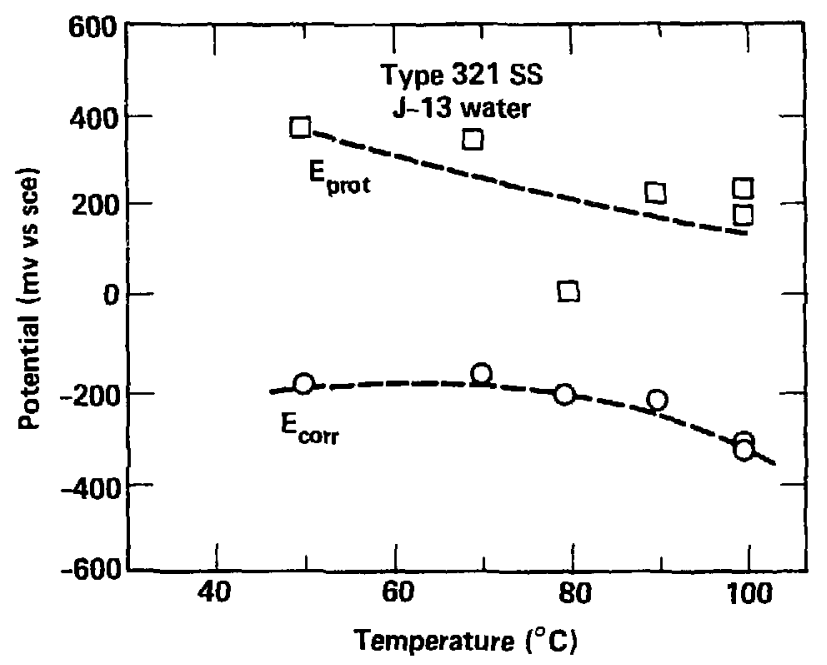

Figure 7 Corrosion Potentials and Protection Potentials for 321 Stainless Steel in Tuff-Conditioned $\mathrm{J}-13$ Water at Different Femperatures 


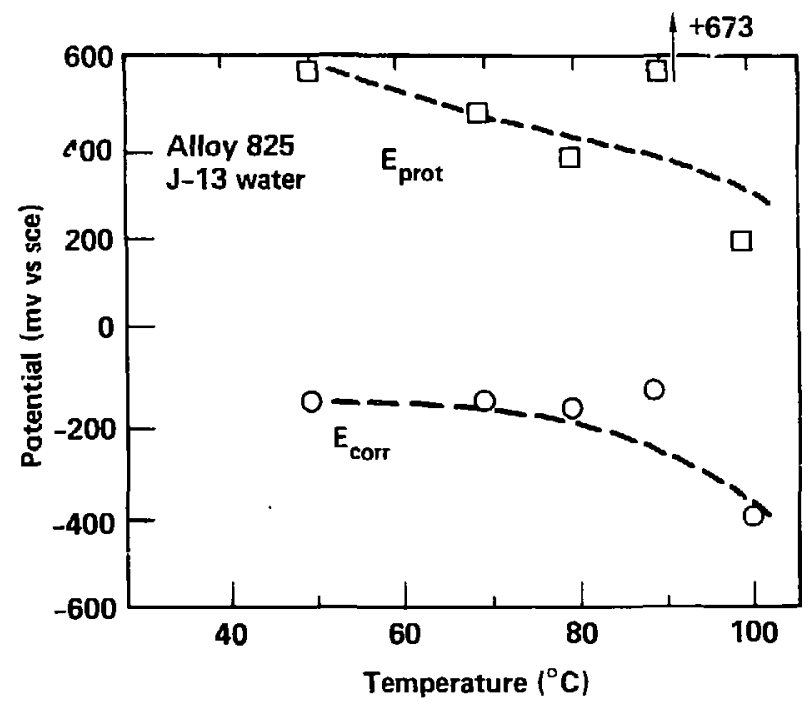

Figure 8 Corrosion Potentials and Protection Potentials for Alloy 825 in Tuff-Conditioned J-13 Water at Different Temperatures 